\title{
RESEARCH ARTICLE \\ The Thermohydraulic Characteristics Investigation of the Aluminum Alloy Monometallic Plate-finned Tube in Together with Numerical Simulation of Heat and Mass Transfer Processes
}

\author{
Sergey V. Tiunov ${ }^{1}$ Ruslan M. Nizamutdinov ${ }^{2 *} \quad$ Ilmir I. Khabibullin $^{2}$ \\ 1. Termocam LLC, Kamsky Polyani, Tatarstan, 423564, Russia \\ 2. Kazan, Tatarstan, 420029, Russia
}

Received: 28 December 2021; Accepted: 23 January 2022; Published Online: 26 January 2022

\begin{abstract}
The article is devoted to the investigation of aluminium alloy plate-finned tube characteristics regarding the heat exchange intensification. Outer thick finning, inner ribs quantity and rib shape allow to increase heat exchange efficiency. However, the most important task is finding an optimal combination of pipe geometry parameters. Seven different ribbed tube samples were investigated during the experiment. The samples differed by geometry, quality and quantity of ribbing, and consequently hydraulic and thermodynamic characteristics. The main criteria for an integrated assessment of pressure losses and energy indicators were the criteria of Kirpichev and Antufiev. The above evaluation criteria were intended for an overall assessment of sample effectiveness based on experimental data. In advance and parallel with a natural experiment, a numerical experiment was conducted. The purpose of the numerical experiment was obtaining an adequate model of the heat exchange section to be used in a full-sized oil cooler model in the future. Thus, the article discusses the results of comparing natural and numerical investigations and the prospect of using the best sample in the oil cooler composition. The ultimate goal is the development of an automatic air-cooling apparatus with a compact high-performance oil cooler.
\end{abstract}

Keywords: Plate-finned tube, Heat exchange section, Oil cooler, Air-cooled heat exchanger, Air-to-oil heat exchanger, Intensifier, Outer fin, Inner rib, Fin pitch, Rib height, Channel wall thickness, Tube width, Tube height; Inner channel quantity, Full-scale experiment, Numerical investigation, Thermal power, Thermal efficiency

\section{Introduction}

Air-cooled heat exchangers are used in different domains, including nuclear, aviation, chemical, oil and gas extracting industries. Despite the fact that a heat exchanger is a part of support equipment, its role in operation of primary equipment is extremely significant.

The key and characteristic element of any oil cooler is the cooling (or heat exchange) section, which can consist of smooth or finned tubes that intensify heat transfer. This is well known that the heat exchange intensifier usage ${ }^{[1]}$

\footnotetext{
*Corresponding Author:

Ruslan M. Nizamutdinov,

Kazan, Tatarstan, 420029, Russia;

Email: ruslan.nizamutdinov@niitk.ru
}

DOI: https://doi.org/10.54963/neea.v1i1.23

Copyright (C) 2022 by the author(s). Published by UK Scientific Publishing Limited. This is an open access article under the Creative Commons Attribution (CC BY) license (https://creativecommons.org/licenses/by/4.0/). 
is the best way to decrease overall size, increase energy efficiency and reduce the cost of heat exchange apparatus, in the whole. The most spread rib types are represented in Figure $1^{[1-4]}$.

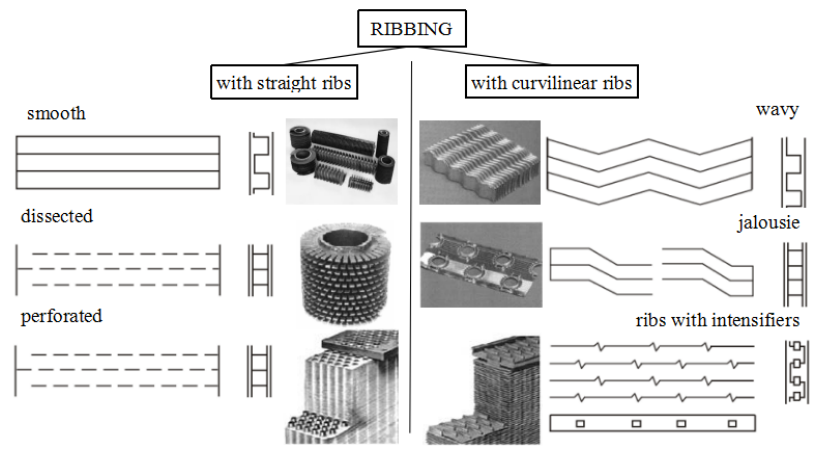

Figure 1. Types of ribbing

This study represents some results of natural and numerical investigations of lamellar-ribbed tube samples. The samples are made of aluminium alloy and in fact, they are varieties of monometallic tubes with dissected ribbing (Figure 2). According to study ${ }^{[6]}$, the heat transfer coefficient of a dissected (serrated) finned tube is 20 percent more than smooth finned tube. Low transitional thermal resistance and high thermal conductivity in combination with cheap manufacturing make the aluminum alloy monometallic flat tube usage preferable in comparison with a steel round spiral-finned tube.

The objective of this study is a trial and subsequent analysis of quantitative thermohydraulic characteristics of the lamellar-ribbed monometallic aluminium alloy flat tube obtained during natural and numerical experiments. The most effective design could be applied in an automatic air-cooled heat exchanger.

\section{Materials and Methods}

\section{Experimental Investigation}

Firstly, some results of the experimental research of airto-oil heat exchanger elements are viewed. The element (a monometallic tube) with developed heat exchange surface made of aluminium alloy is shown in Figure 2.

The crosscuts of the cooling section with six inner channels are shown in Figures 3. The tube has a rectangular profile with inner channels (Figure 3a) produced with mechanical tools. There are specially formed fins on the outer surface providing the intense heat transfer with air. The longitudinal solid edges in the inner rectangular channels have oil side mass and heat transfer intensifiers (Figure 3b, 3c).
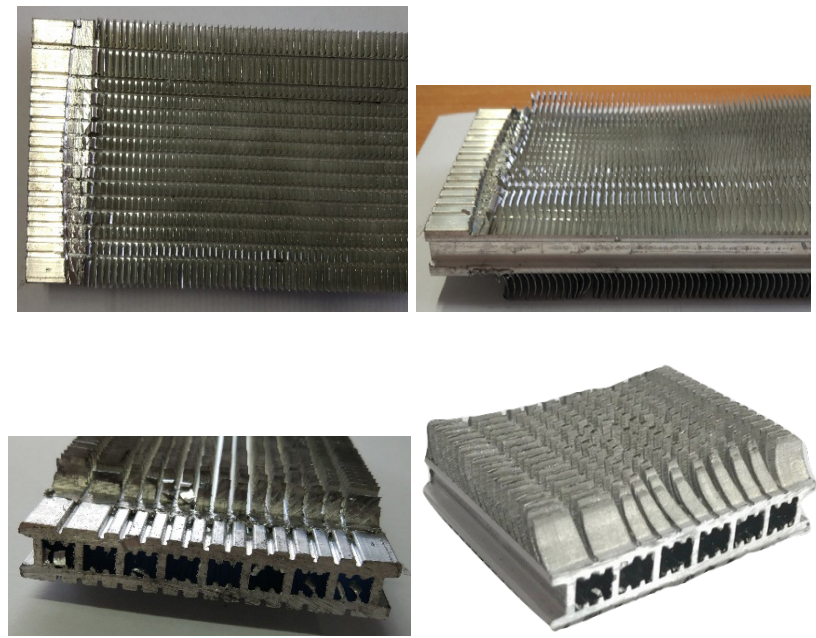

Figure 2. Monometallic tube (cooling section) samples

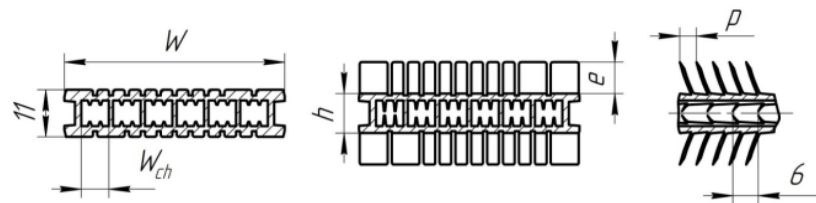

a)

b)

c)

Figure 3. The cooling section ${ }^{[5]}$ : a) tube profile; b), c) cooling section profile

Figure 4 illustrates a scheme of the test rig, which was used to get the quantitative heat and hydrodynamic characteristics of the cooling section during the research.

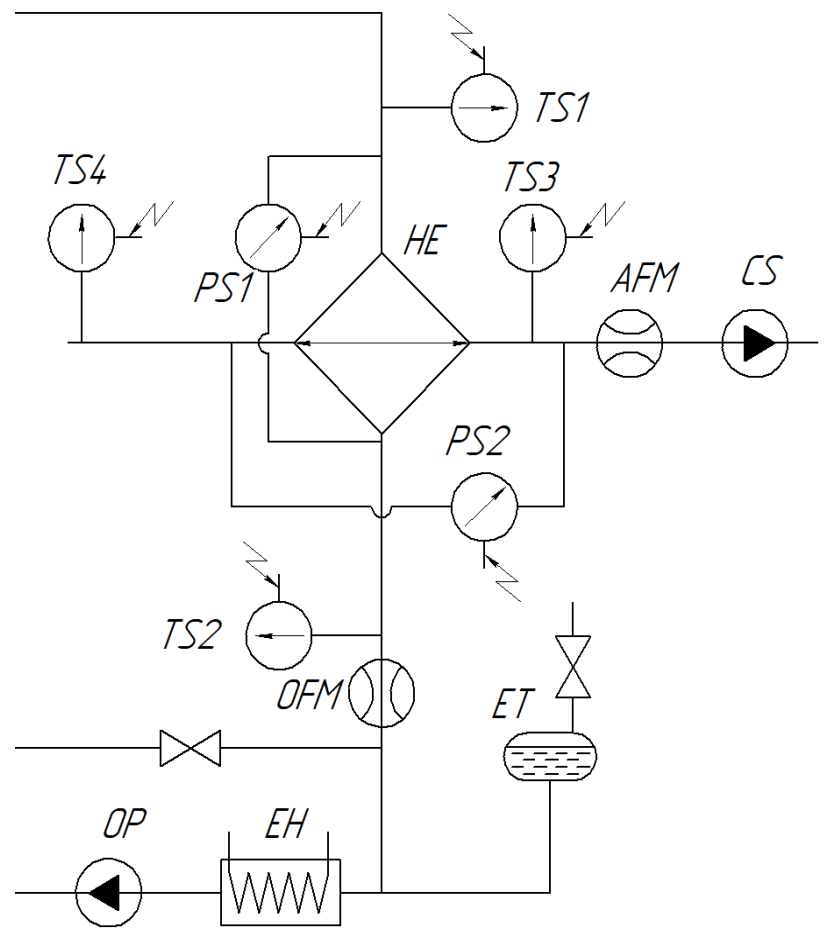

Figure 4. Test rig scheme 
The scheme includes: a characteristic element (a single cooling air-to-oil heat exchanger section) HE; an oil pump $\mathrm{OP}$; an oil electric heater $\mathrm{EH}$; an oil ultrasonic flow meter OFM; an expansion tank ET; oil temperature sensors TS1-TS2; differential pressure sensors PS1-PS2; an air centrifugal supercharger CS; an air flow meter AFM; air temperature sensors TS3-TS4. Measuring means list is represented in Table 1.

Table 1. The measuring means list

\begin{tabular}{ccc}
\hline Name, type and marking & Quantity & $\begin{array}{c}\text { Standard, Specification or } \\
\text { designation }\end{array}$ \\
\hline $\begin{array}{c}\text { Sixteen channel stationary } \\
\text { air velocity meter }\end{array}$ & 1 & $\begin{array}{c}\text { TTM-2/16-06-8P-8A by } \\
\text { «EKSYS» firm } \\
\text { TTM-2-04-01 by«EKSYS» } \\
\text { Thermo anemometer }\end{array}$ \\
firm \\
Power supply & 1 & TPM138 \\
Pressure sensor & 1 & AIR 20/M2-DD \\
Pressure sensor & 1 & OVEN PD200 \\
Pump, heater & 1 & PFM1-4 \\
Ultrasonic flow meter & 1 & PortoFlow330 \\
Temperature sensor & 4 & Pt-100 \\
Centrifugal supercharger & 1 & VR 132-30-8 \\
\hline
\end{tabular}

PFM1-4 unit ( $5 \mathrm{~kW}$ power and $4 \mathrm{~m}^{3} / \mathrm{hr}$ capacity) was implemented into the test rig to pump and heat coolant. VR 132-30-8 centrifugal supercharger (15 kW power at $1500 \mathrm{rpm}$ ) was used for cooling air feeding. OVEN PCHV 204-15K-V frequency control device, realized adjustment of centrifugal supercharger frequency. Working fluid was TP-22C oil (technical specification TU 38.101821-2013).

Special connecting pipes with seats for pressure and temperature sensors were designed and printed with $3 \mathrm{D}$ printer to provide the uniform oil flow rate in the heat exchanger channels, shown in Figure 5.

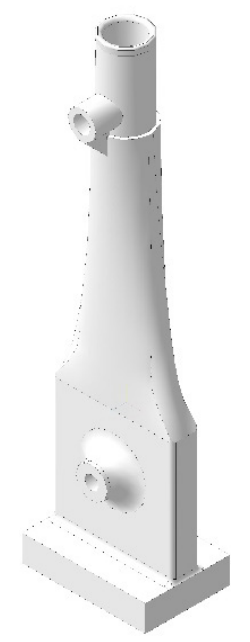

Figure 5. The connecting pipe
Table 2. Defined parameters and their measurement accuracy

\begin{tabular}{|c|c|c|c|}
\hline No & Parameter name & $\begin{array}{c}\text { Measure } \\
\text { unit }\end{array}$ & $\begin{array}{c}\text { Measurement } \\
\text { limit deviations }\end{array}$ \\
\hline 1. & Oil heat exchanger inlet temperature & ${ }^{\circ} \mathrm{C}$ & $2 \%$ \\
\hline 2. & $\begin{array}{c}\text { Oil heat exchanger outlet } \\
\text { temperature }\end{array}$ & ${ }^{\circ} \mathrm{C}$ & $2 \%$ \\
\hline 3. & $\begin{array}{c}\text { Air heat exchanger input } \\
\text { temperature }\end{array}$ & ${ }^{\circ} \mathrm{C}$ & $2 \%$ \\
\hline 4. & $\begin{array}{l}\text { Air heat exchanger output } \\
\text { temperature }\end{array}$ & ${ }^{\circ} \mathrm{C}$ & $2 \%$ \\
\hline 5. & Oil flow meter indication & litre/minute & $1 \%$ \\
\hline 6. & $\begin{array}{c}\text { Air velocity indication in the } \\
\text { channel }\end{array}$ & $\mathrm{m} / \mathrm{s}$ & $3 \%$ \\
\hline 7. & Air velocity before cooling section & $\mathrm{m} / \mathrm{s}$ & $3 \%$ \\
\hline 8. & Air velocity after cooling section & $\mathrm{m} / \mathrm{s}$ & $3 \%$ \\
\hline 9. & $\begin{array}{c}\text { Air temperature after cooling } \\
\text { section }\end{array}$ & ${ }^{\circ} \mathrm{C}$ & $3 \%$ \\
\hline 10. & $\begin{array}{l}\text { Air temperature before cooling } \\
\text { section }\end{array}$ & ${ }^{\circ} \mathrm{C}$ & $3 \%$ \\
\hline 11. & Air drop pressure & $\mathrm{Pa}$ & $\pm 3 \%$ \\
\hline 12. & Oil drop pressure & $\mathrm{Pa}$ & $\pm 3 \%$ \\
\hline
\end{tabular}

Instruments and experiment technique are described below the passage. The oil temperature at the heat exchanger inlet and outlet was measured with PT100 resistance thermometers and RMT-59 register to determine the heat flow. The oil flow value was determined with Porto Flow 330 ultra-sonic flow meter. Simultaneously, the heat flow determination in the second (air) contour was performed by measurement of input and output temperatures and the air flow rate value. Table 2 represents the list of defined parameters and their measurement accuracy.

Seven samples of monometallic tube were investigated during the research. Table 3 represents the basic geometric parameters of the test samples.

Table 3. Geometrical characteristics of monometallic tube samples (Figure 3)

\begin{tabular}{|c|c|c|c|c|c|c|c|}
\hline $\begin{array}{c}\text { Sample } \\
\text { No }\end{array}$ & $\begin{array}{c}\text { Fin } \\
\text { pitch } \\
p, \\
{[\mathrm{~mm}]}\end{array}$ & $\begin{array}{c}\text { Fin } \\
\text { height } \\
\mathrm{e}, \\
{[\mathrm{mm}]}\end{array}$ & $\begin{array}{c}\text { Channel } \\
\text { wall } \\
\text { thickness } \\
\text { of the } \\
\text { tube, } \\
\text { [mm] }\end{array}$ & $\begin{array}{c}\text { Tube } \\
\text { width W, } \\
{[\mathrm{mm}]}\end{array}$ & $\begin{array}{c}\text { Tube } \\
\text { height } \\
\text { h, }[\mathrm{mm}]\end{array}$ & $\begin{array}{c}\text { Inner } \\
\text { channel } \\
\text { quantity, } \\
\text { pcs }\end{array}$ & $\begin{array}{c}\text { Inner } \\
\text { channel } \\
\text { width } \\
\mathrm{W}_{\mathrm{ch}}, \\
{[\mathrm{mm}]}\end{array}$ \\
\hline 1 & 2 & 8.5 & 1.2 & 52 & 8.0 & 6 & 6 \\
\hline 2 & 2 & 6,5 & 1.2 & 52 & 8.5 & 6 & 6 \\
\hline 3 & 2,5 & 4 & 1.2 & 52 & 8.5 & 6 & 6 \\
\hline 4 & 3.75 & 5.5 & 1.2 & 52 & 8.5 & 6 & 6 \\
\hline 5 & 2.5 & 8 & 1.2 & 67.5 & 8.3 & 8 & 6 \\
\hline 6 & 2.5 & 8 & 1.2 & 67.5 & 8.5 & 8 & 6 \\
\hline 7 & 3.75 & 6 & 1.2 & 67.5 & 9.2 & 8 & 6 \\
\hline
\end{tabular}

he experimental results were processed according to the following equations ${ }^{[2]}$.

Heat capacity:

$\mathrm{Q}=\mathrm{c}_{\mathrm{p}} \cdot \mathrm{G} \cdot \Delta \mathrm{T}_{\max }$, 
where Q is the heat capacity of the cooling section, W; $\mathrm{c}_{\mathrm{p}}$-the specific heat capacity at the constant pressure, $\mathrm{J} /$ $(\mathrm{kg} \cdot \mathrm{K})$;

G-the coolant mass flow, $\mathrm{kg} / \mathrm{s}$;

$\Delta \mathrm{T}_{\max }$-the maximal temperature deference of the coolant at the input and the output, ${ }^{\circ} \mathrm{C}$.

The total thermal resistance to heat transfer:

$R=1 / k$,

where $\mathrm{k}$ is the heat transfer coefficient, $\left(\mathrm{m}^{2} \mathrm{~K}\right) / \mathrm{W}$, determined by formula

$k=Q /(F \cdot \overline{\Delta t})$,

where $\mathrm{F}$ is the outer surface heat transfer area without accounting of fins, $\mathrm{m}^{2}$, determined by formula

$F=2 \cdot(W+h) \cdot L$,

where $\overline{\Delta t}$ is the average logarithmic temperature head of the cooling section at the transverse flow.

The next parameter is a compactness factor, $\mathrm{m}^{2} / \mathrm{m}^{3}$, determined by formula

$k_{C P}=F / V$,

where $\mathrm{F}$ is the surface heat transfer area, $\mathrm{m}^{2}$, of any coolant side to the cooler core (matrix) volume, $\mathrm{m}^{3}$.

The cooling section thermal efficiency was calculated by the next formula

$\eta=Q / Q_{\max }$

where $\mathrm{Q}$ is the heat capacity and $\mathrm{Q}_{\max }$ is the highest possible heat capacity, $\mathrm{W}$, of the cooling section.

\section{Results}

Measurement data processing results for seven samples are represented in Table 4.

After processing measurement results, thermal power on mode parameters graphical dependencies were obtained for every sample, Figure 6.
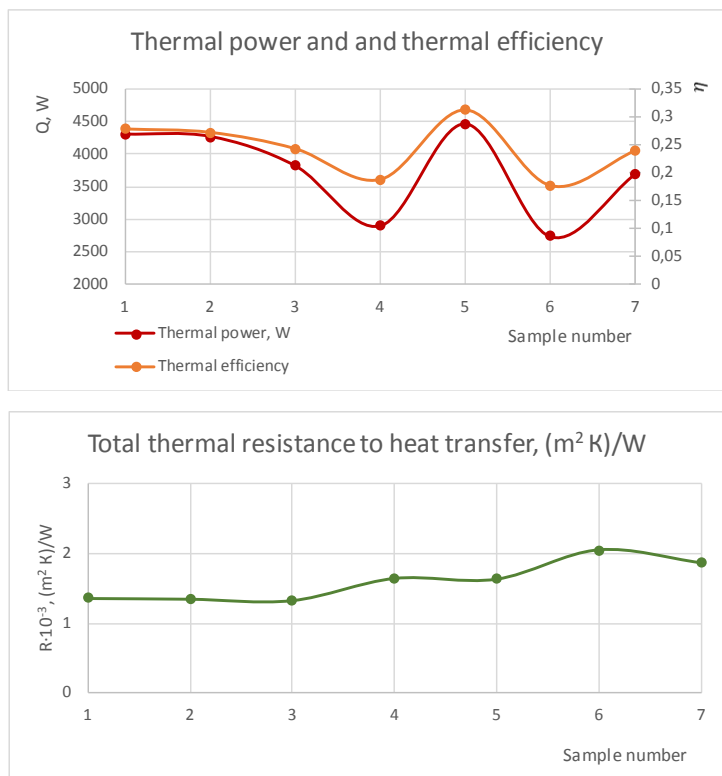

Specific gravity of the flat-finned tube, $\mathrm{kg} / \mathrm{m}$

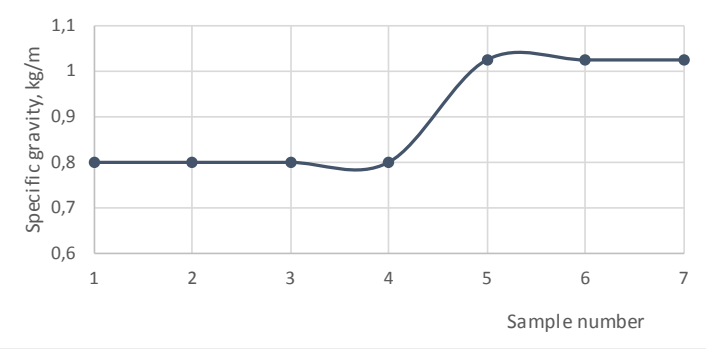

Compactness factor, $\mathrm{m}^{2} / \mathrm{m}^{3}$

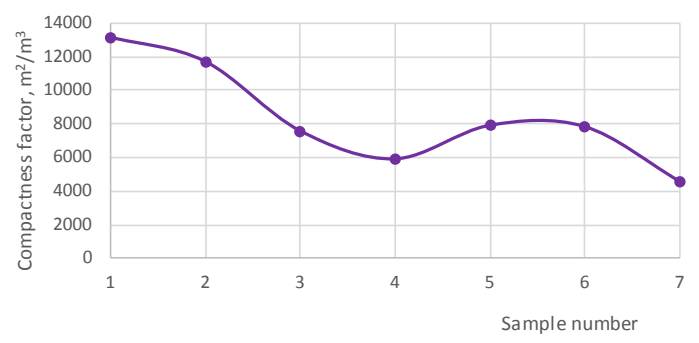

Table 4. Thermal characteristics of monometallic tube samples

\begin{tabular}{|c|c|c|c|c|c|}
\hline Sample No & Thermal power, $\mathrm{W}$ & Thermal efficiency & $\begin{array}{l}\text { Total thermal resistance to } \\
\text { heat transfer, }\left(\mathrm{m}^{2} \mathrm{~K}\right) / \mathrm{W}\end{array}$ & $\begin{array}{l}\text { Specific gravity of the flat- } \\
\text { finned tube* }, \mathrm{kg} / \mathrm{m}\end{array}$ & $\begin{array}{c}\text { Compactness factor, } \\
\mathrm{m}^{2} / \mathrm{m}^{3}\end{array}$ \\
\hline 1 & 4302 & 0,278 & $1,36 \cdot 10^{-3}$ & 0,802 & 13156 \\
\hline 2 & 4267 & 0,272 & $1,35 \cdot 10^{-3}$ & 0,802 & 11720 \\
\hline 3 & 3821 & 0,243 & $1,33 \cdot 10^{-3}$ & 0,802 & 7580 \\
\hline 4 & 2905 & 0,188 & $1,64 \cdot 10^{-3}$ & 0,802 & 5888 \\
\hline 5 & 4457 & 0,312 & $1,63 \cdot 10^{-3}$ & 1,025 & 7885 \\
\hline 6 & 2738 & 0,177 & $2,04 \cdot 10^{-3}$ & 1,025 & 7821 \\
\hline 7 & 3700 & 0,24 & $1,86 \cdot 10^{-3}$ & 1,025 & 4566 \\
\hline
\end{tabular}

* the monometallic flat-finned tube one meter weight 

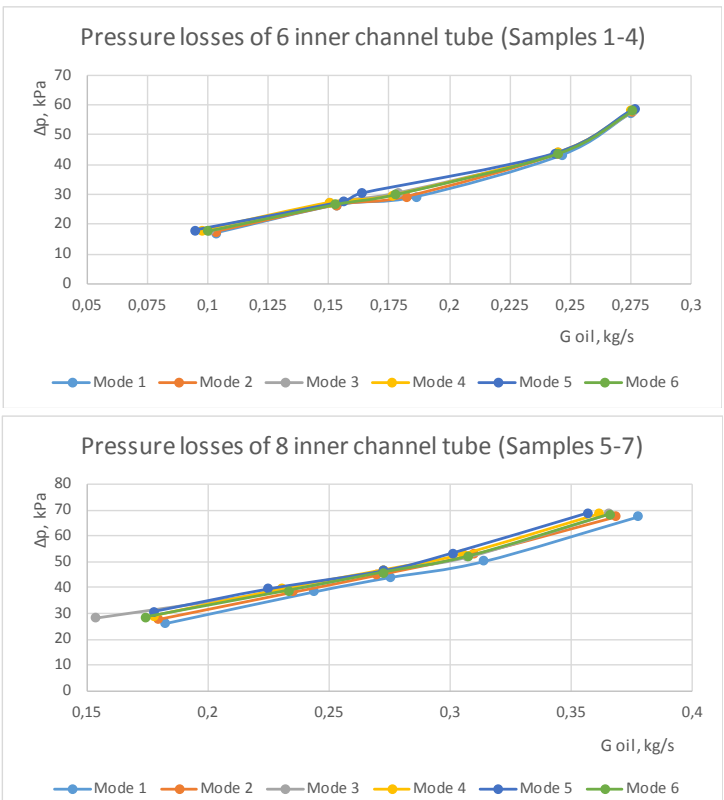

Figure 6. Graphical dependencies of measurement data processing results for seven samples

Figures 7 illustrates thermal power dependencies on oil-side Reynolds numbers at fixed air-side Reynolds numbers for samples 2 and 5 respectively.

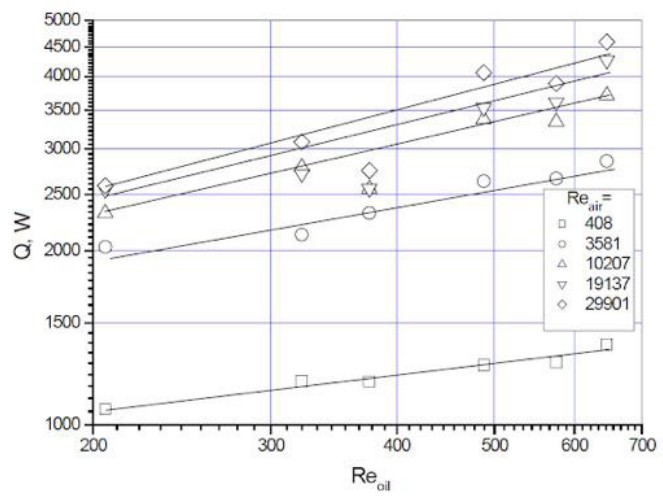

a) sample 2

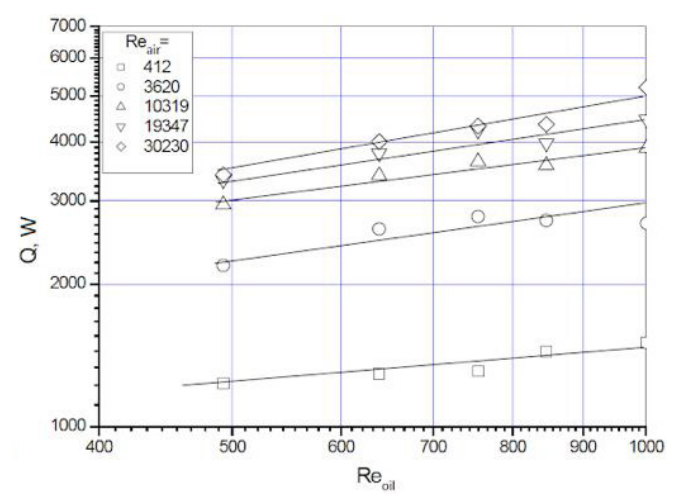

b) sample 5

Figure 7. Thermal power on mode parameters graphical dependencies for samples 2 and 5
Figure 8 shows the comparison of test samples by Kirpichev energy efficiency criterion-E ${ }^{[9]}$, which is determined by formula

$E=Q / N$,

where Q is the heat capacity, W, see formula (1),

$\mathrm{N}$-the pumping power of oil and/or air, W, which is determined by formula

$N=G \cdot \Delta P /(\rho \cdot \eta)$,

where G-the oil/air mass flow, $\mathrm{kg} / \mathrm{s}$,

$\Delta \mathrm{P}$-oil/air side pressure losses, $\mathrm{Pa}$,

$\rho$-oil/air density, $\mathrm{kg} / \mathrm{m}^{3}$,

$\eta$-the efficiency factor of a pump or ventilator.

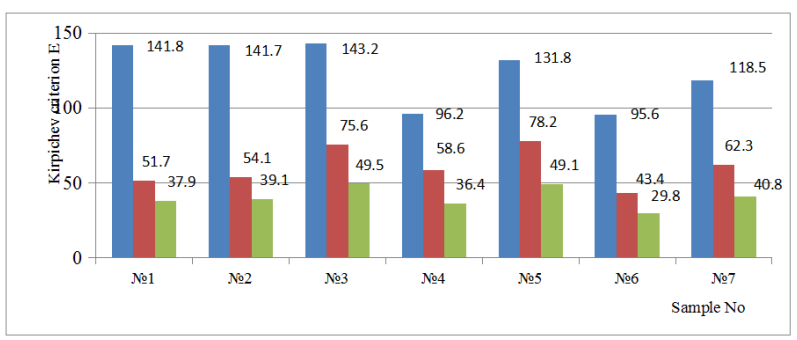

Figure 8. Kirpichev energy efficiency criterion (E) of test samples: $\square \mathrm{N}_{\text {air }}$ calculation, $\square \mathrm{N}_{\text {oil }}$ calculation, $\square\left(\mathrm{N}_{\text {air }}+\right.$ $\mathrm{N}_{\text {oil }}$ ) calculation.

Figure 9 illustrates the graphical comparison of test samples by Antufiev energy efficiency criterion ${ }^{[10]}$ determined by formula

$E^{\prime}=Q /(N \cdot \overline{\Delta t})$,

where Q is the heat capacity, W, formula (1),

$\mathrm{N}$ is the pumping power of oil and/or air, W, formula (8),

$\overline{\Delta t}$ is the average logarithmic temperature head of the cooling section at the transverse flow.

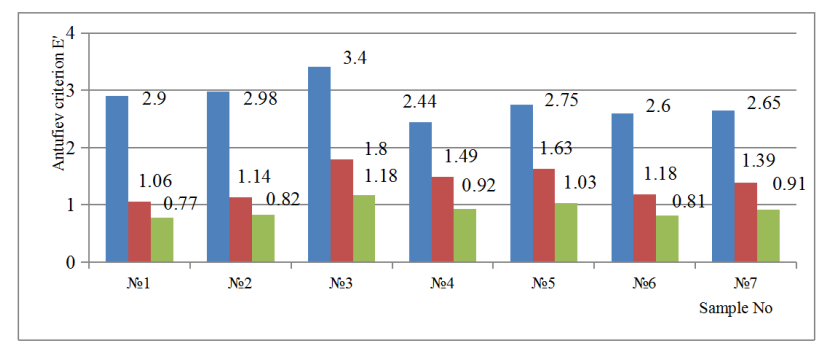

Figure 9. Antufiev energy efficiency criterion () of test samples: $\square \mathrm{N}_{\text {air }}$ calculation, $\square \mathrm{N}_{\text {oil }}$ calculation, $\square\left(\mathrm{N}_{\text {air }}+\right.$ $\mathrm{N}_{\mathrm{oil}}$ ) calculation.

\section{Numerical investigation}

Numerical modeling was undertaken to obtain an adequate model of the heat exchange section, in order to subsequently create full-sized models, firstly, of oil cooler and, secondly, automatic air-to-oil heat exchanger. Thus, 
obtaining the characteristic oil cooler element numerical model is the first step for further processes simulation of the full-sized apparatus. Process simulation was performed in the ANSYS ${ }^{\circledR}$ environment.

In view of the fact that the heat exchange (cooling) section is a flat-finned pipe of strict geometry with periodically repeating items (outer and inner fins, inner channels), the simulation methodology is based on the calculation of the heat exchange section element (shown in Figure 10) at average oil temperatures. Obtaining the general thermal and hydraulic characteristics of the whole section is done by multiplying by the corresponding amount of these elements along the cooling section. The regular element (Figure 10) is built with CAD tools and corresponds with the schemes shown in Figure 3 and photo in Figure 2. This is the first step in building a numerical model-geometric.

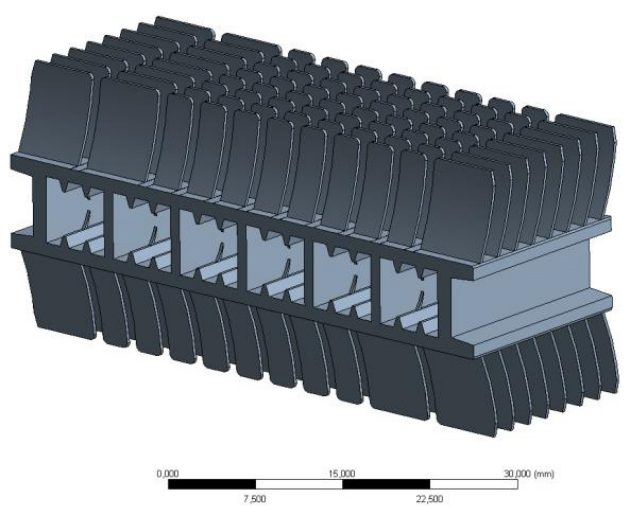

Figure 10. Regular element of the heat exchange section

The second step is creating air side and oil side working fluid domains. The domains are extended to simulate the heat cooling section before and after the regular element (see Figure 11).

At the third step, a finite element (FE) mesh is constructed for each domain. An ANSYS Meshing grid generator is used to create a FE-volume model of the computational grid. The calculated domain grids shown in Figures.

The FE mesh regular element model has 2945346 nodes, the air domain has 4244246 nodes, and the oil domain has 7967807 nodes. Prismatic sub-layers are constructed for the air and oil domain. The minimum cell size is $0.1 \mathrm{~mm}$.

The boundary conditions at the inlet and outlet calculated area of the external air and oil circuits are velocity and pressure change terms, temperature and flow values, permeability coefficients, porosity coefficients, double cell model for simulating the heat transfer process between external air and oil circuits. The efficiency of the oil cooler is determined by the dependence on air and oil flow rates, according to nature experiments.

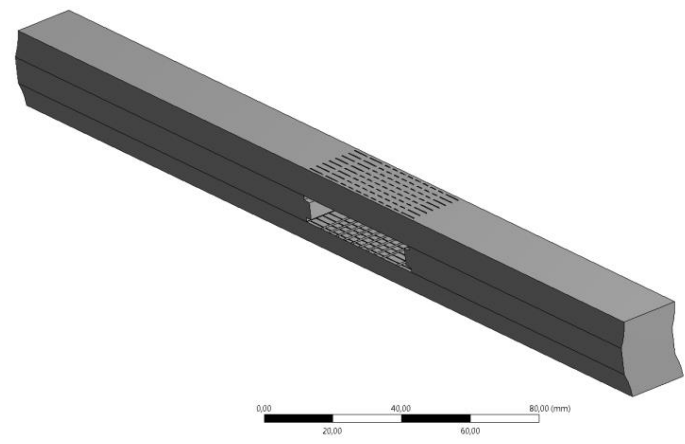

a) air carrier domain

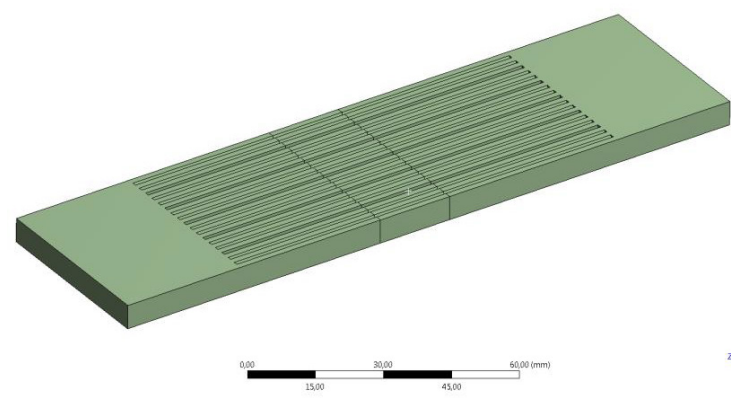

b) oil carrier domain

Figure 11. Working fluid domains
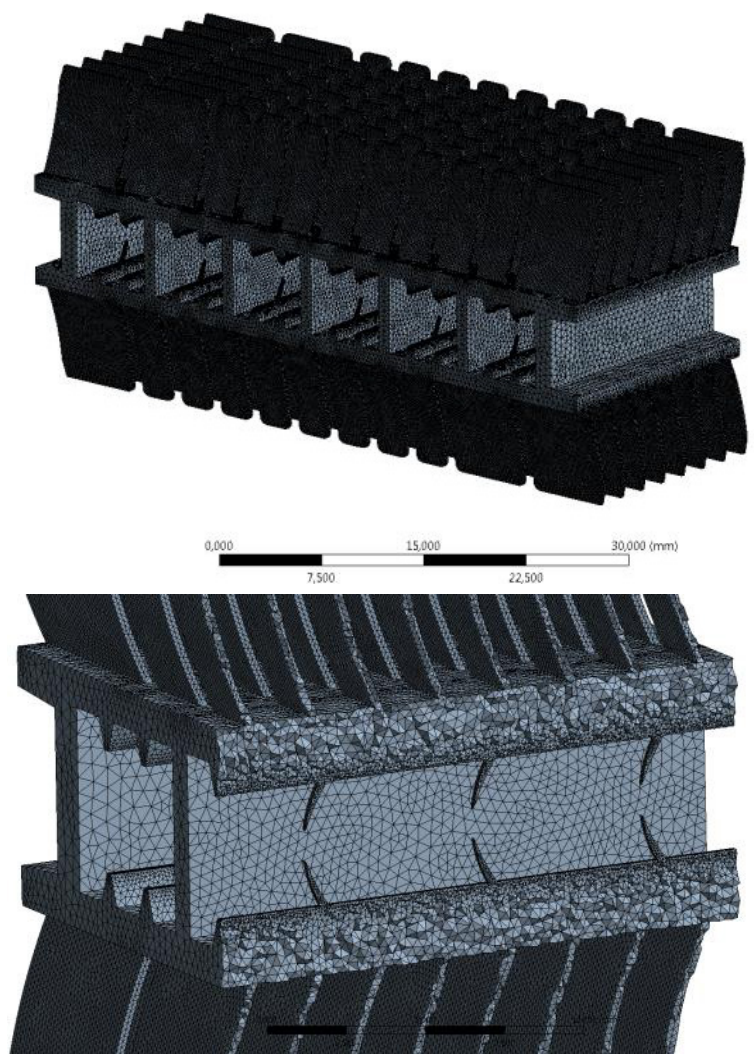

Figure 12. The regular item FE grid 


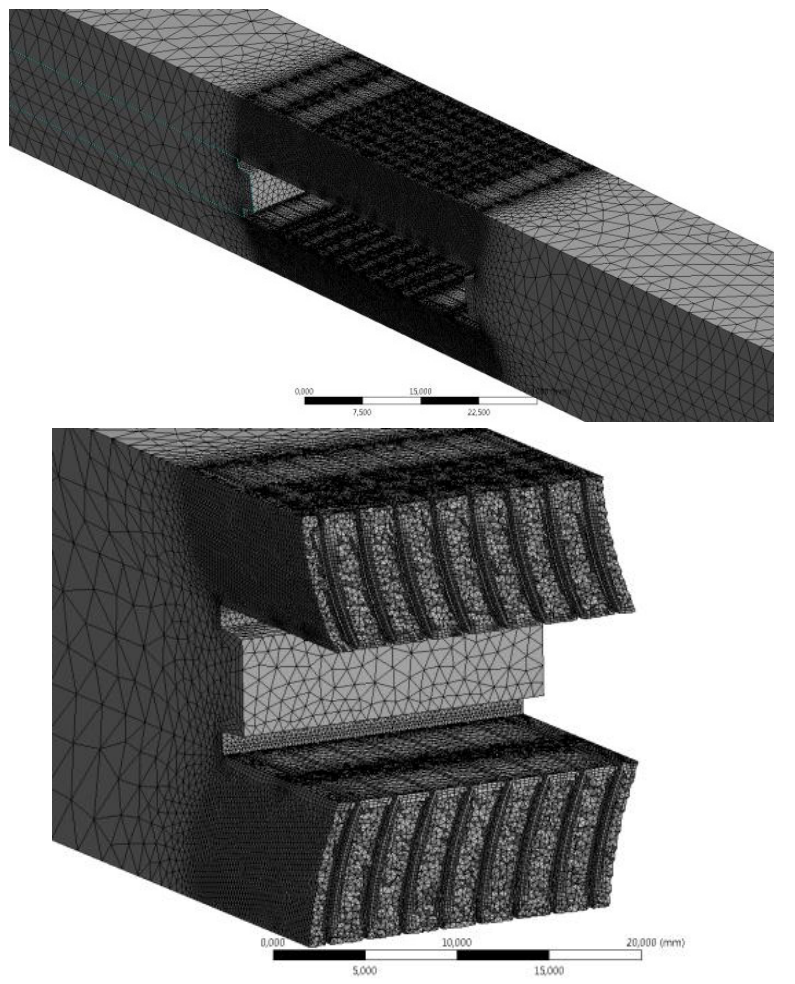

Figure 13. The air domain FE grid
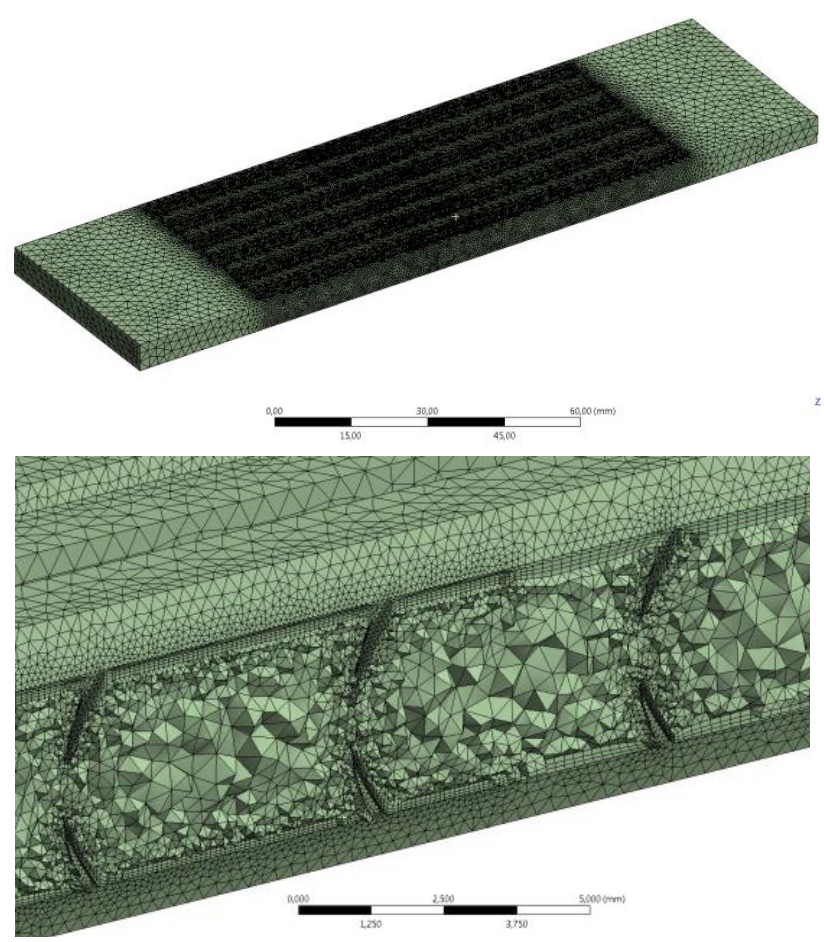

Figure 14. The oil domain FE grid

Then, the FE grids of the computational domains are transferred to CFX ANSYS ${ }^{\circledR}$, where boundary conditions are assigned (Figure 15). The following boundary conditions are assigned for the regular item: air velocity at the element inlet $7.96 \mathrm{~m} / \mathrm{s}$, temperature $20^{\circ} \mathrm{C}$, mass oil flow through the element $0.148 \mathrm{~kg} / \mathrm{s}$, oil temperature 65 ${ }^{\circ} \mathrm{C}$. The BSL model is used to calculate the task.
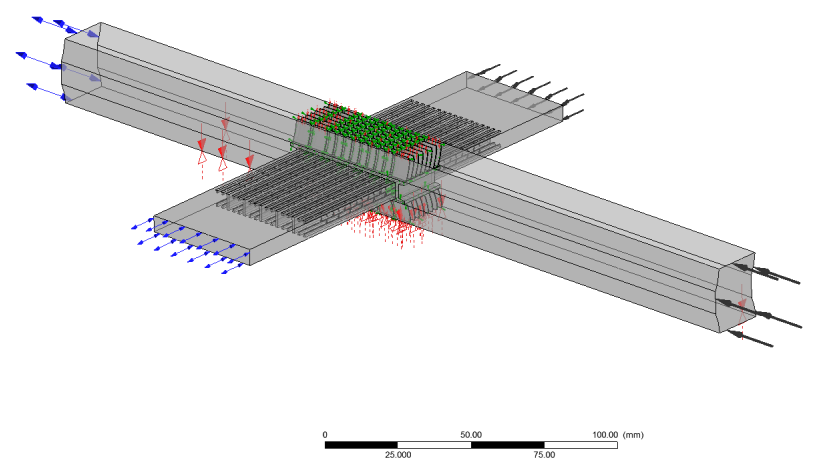

Figure 15. Boundary conditions

The calculation results of pressure, temperature, and velocity fields are presented in Figures 16-19. The air flow structure is shown in Figure 19b.

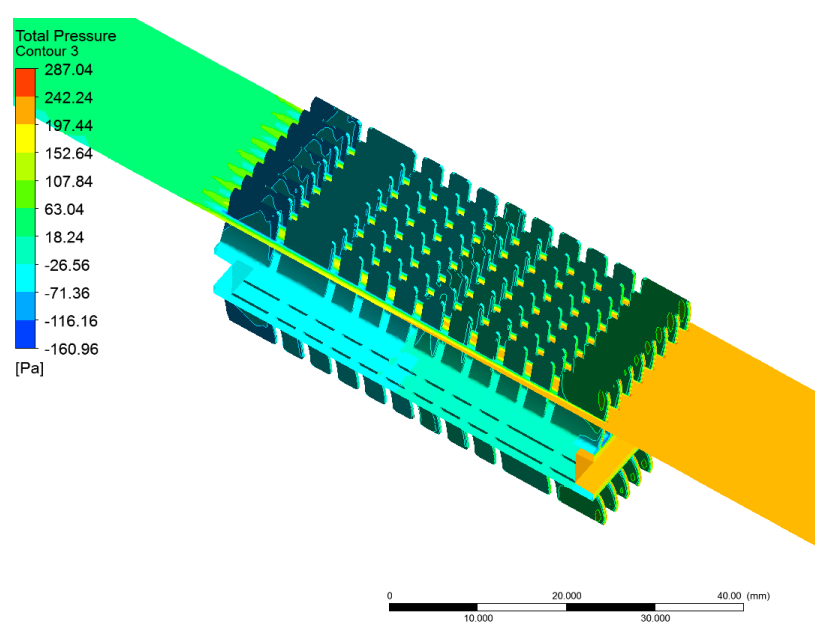

a)

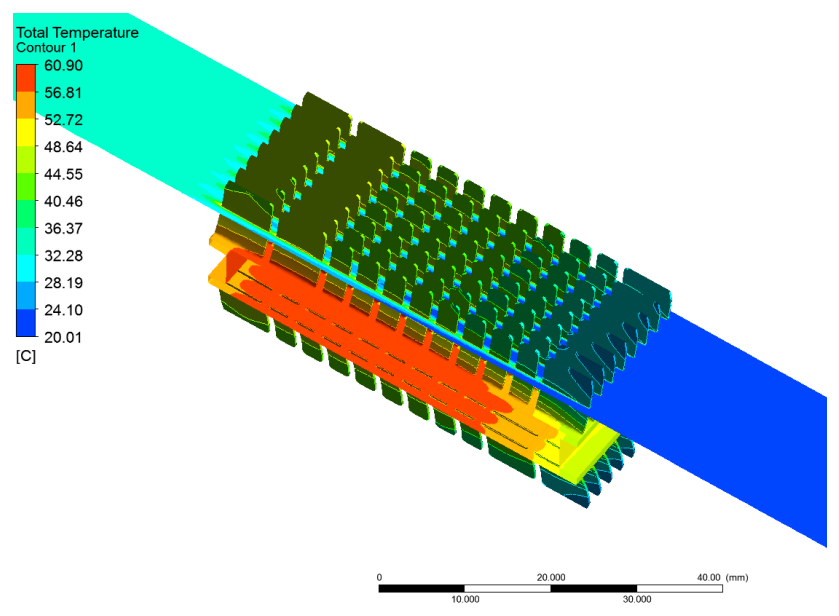

b)

Figure 16. Pressure (a) and temperature (b) fields in the air path 


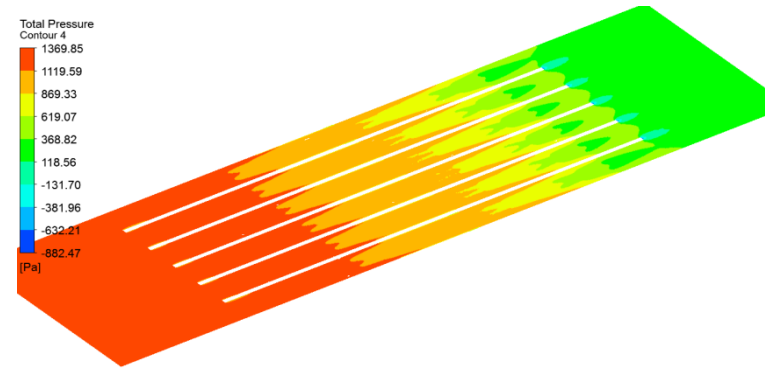

a)

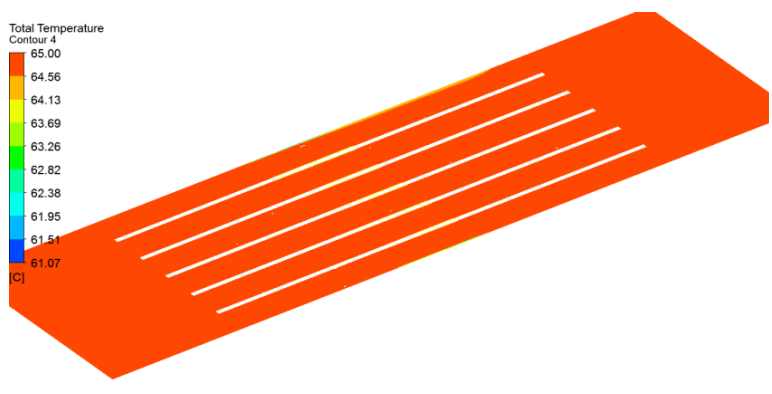

b)

Figure 17. Pressure (a) and temperature (b) fields in the oil path.

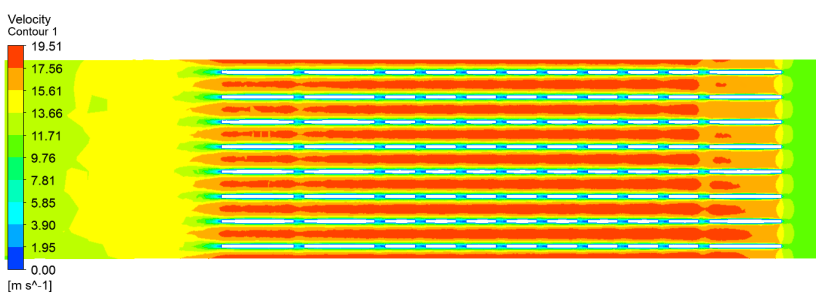

a)

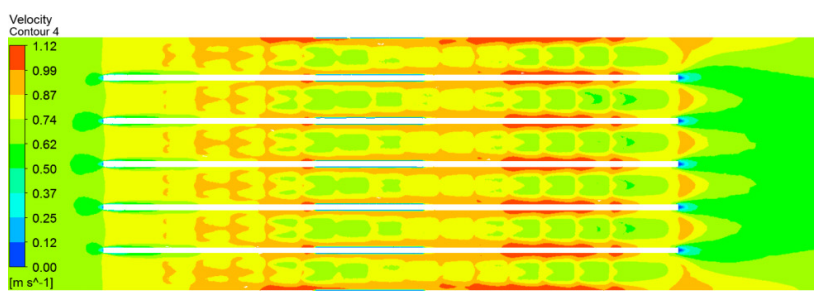

b)

Figure 18. Velocity fields in the air (a) and oil (b) path.

The numerical experiment results are summarized in Tables 5-9 and presented by graphical dependencies in Figures 20-22 below.

Table 9 summarizes the numerical study results of pressure losses in a single channel with and without ribs. The graph in Figure 22 clearly illustrates the difference in pressure loss values during oil flow in a finned and smooth channel.

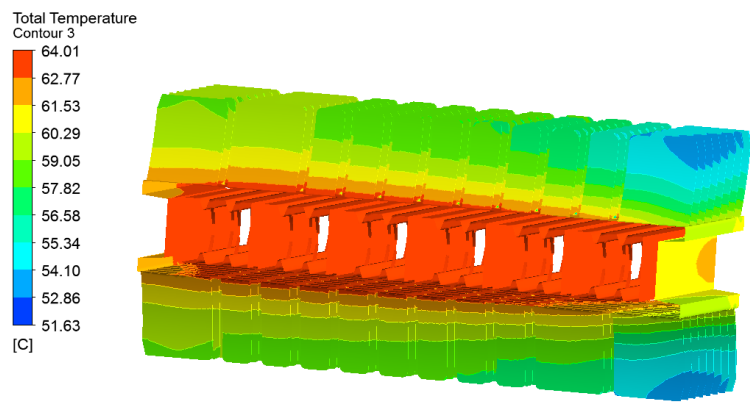

a)

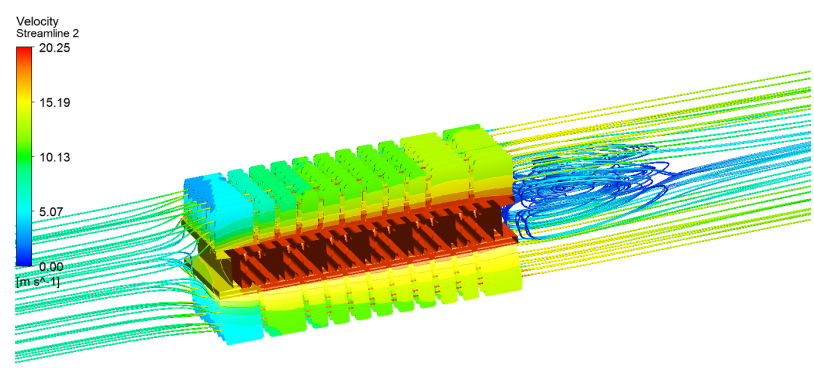

b)

Figure 19. Temperature fields on the internal and external interfaces (a) and air domain flow structure (b)

Table 5. Thermal power in dependency on air and oil mass flow rates

\begin{tabular}{cccccc}
\hline \multirow{2}{*}{$\begin{array}{c}\text { Air mass } \\
\text { flow rate }\end{array}$} & \multicolumn{5}{c}{ Oil mass flow rate $\mathrm{G}_{\text {oil }}, \mathrm{kg} / \mathrm{s}$} \\
\cline { 2 - 6 } $\mathrm{G}_{\text {air }} \mathrm{kg} / \mathrm{s}$ & 0,1791 & 0,2344 & 0,2738 & 0,3088 & 0,3669 \\
\hline 0,0549 & 1234,07 & 1293,71 & 1310,09 & 1440,07 & 1502,95 \\
0,1549 & 2189,97 & 2615,59 & 2779,16 & 2726,19 & 2683,97 \\
0,2601 & 2943,05 & 3391,6 & 3630,68 & 3564,86 & 3878,94 \\
0,3446 & 3320,4 & 3780,62 & 4230,5 & 3969,8 & 4457,31 \\
0,4195 & 3406,98 & 3999,68 & 3314,26 & 4348,85 & 5210 \\
\hline
\end{tabular}

Table 6. Thermal efficiency in dependency on air and oil mass flow rates

\begin{tabular}{cccccccc}
\hline & \multicolumn{7}{c}{ Thermal efficiency $\eta$} \\
\cline { 2 - 7 } Air mass & Oil mass & & & & \\
flow rate & flow rate & 0,1791 & 0,2344 & 0,2738 & 0,3088 & 0,3669 \\
$\mathrm{G}_{\text {air }}, \mathrm{kg} / \mathrm{s}$ & $\mathrm{G}_{\text {oil }}, \mathrm{kg} / \mathrm{s}$ & & & & & \\
\cline { 2 - 8 } & $\mathrm{c}_{\mathrm{p} \mathrm{air}} / \mathrm{c}_{\mathrm{p} \text { oil }}$ & 362,497 & 474,2589 & 553,9499 & 624,8944 & 742,4873 \\
\hline 0,0549 & 55,1328 & 0,5394 & 0,5654 & 0,5726 & 0,6294 & 0,6569 \\
0,1549 & 156,9519 & 0,3362 & 0,4016 & 0,4267 & 0,4185 & 0,4121 \\
0,2601 & 261,3817 & 0,2713 & 0,3127 & 0,3347 & 0,3286 & 0,3576 \\
0,3446 & 346,9078 & 0,231 & 0,2631 & 0,2944 & 0,2762 & 0,3101 \\
0,4195 & 421,5587 & 0,2265 & 0,2286 & 0,2466 & 0,2486 & 0,2978 \\
\hline
\end{tabular}


The thermal power change depending on the air and oil mass flow rates

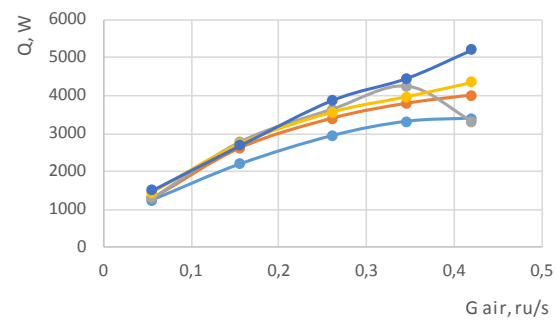

a)

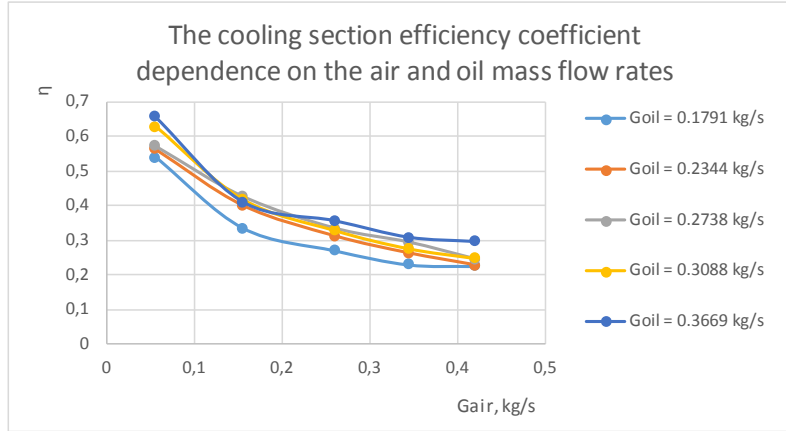

b)

Figure 20. Thermal power and efficiency graphical dependencies on air and oil mass flow rates (determined numerically)

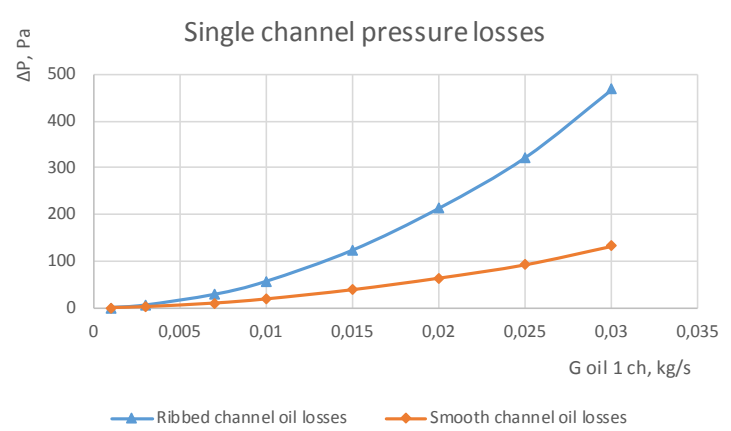

a)
Table 7. Air pressure losses in dependence on air velocity

\begin{tabular}{cccccc}
\hline Parameter & \multicolumn{5}{c}{ Value } \\
\hline $\begin{array}{c}\text { Air flow rate G } \\
\text { air, kg/s }\end{array}$ & 0,0549 & 0,1549 & 0,2601 & 0,3446 & 0,4195 \\
& & & & & \\
$\begin{array}{c}\text { Air velocity w } \\
\text { air, m/s }\end{array}$ & 1,0902 & 3,1036 & 5,1685 & 6,8479 & 8,3359 \\
$\begin{array}{c}\text { Air pressure } \\
\text { losses } \Delta \mathrm{p}, \mathrm{Pa}\end{array}$ & 8,97 & 47,2 & 104,7533 & 165,5333 & 256,5 \\
\hline
\end{tabular}

Table 8. Oil pressure losses in dependence on oil velocity (mass flow rate of the whole section)

\begin{tabular}{cccccc}
\hline Parameter & \multicolumn{5}{c}{ Value } \\
\hline $\begin{array}{c}\text { Oil flow rate G } \\
\text { oil, } \mathrm{kg} / \mathrm{s}\end{array}$ & 0,1791 & 0,2344 & 0,2738 & 0,3088 & 0,3669 \\
& & & & & \\
$\begin{array}{c}\text { Oil velocity w air, } \\
\mathrm{m} / \mathrm{s}\end{array}$ & 0,1237 & 0,1619 & 0,1891 & 0,2133 & 0,2534 \\
& & & & &
\end{tabular}

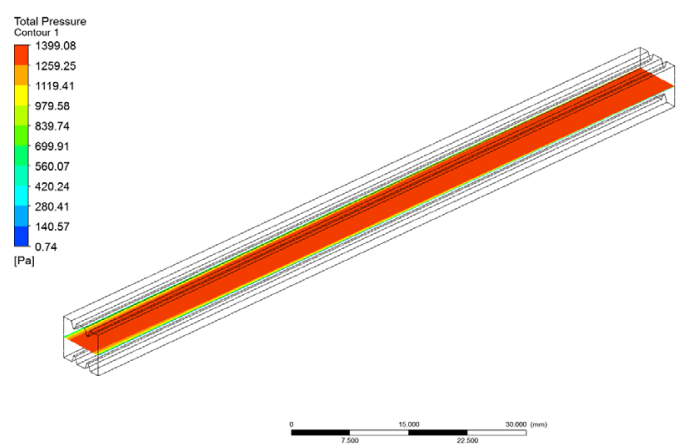

b)

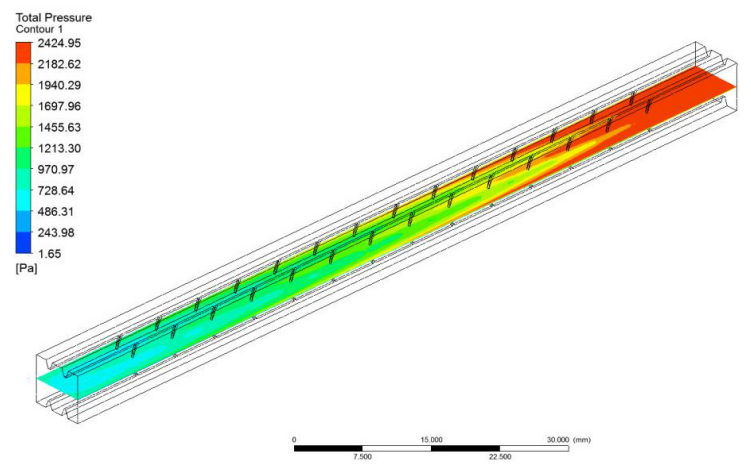

c)

Figure 22. Pressure losses in single channel with and without ribs (a), total pressure in the smooth (b) and ribbed channel (c) 


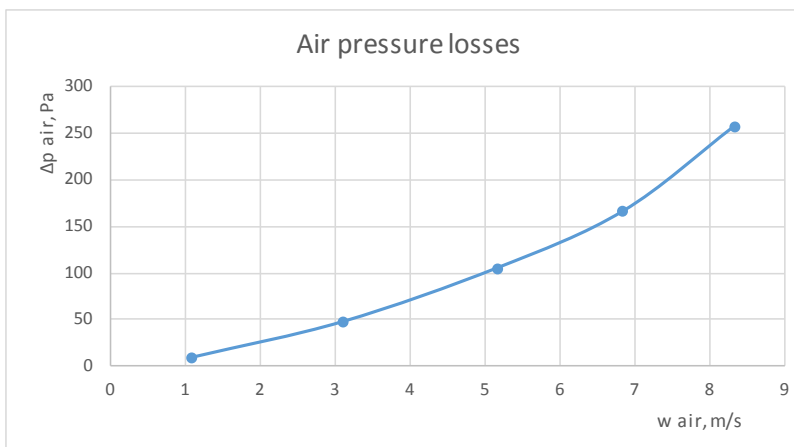

a)

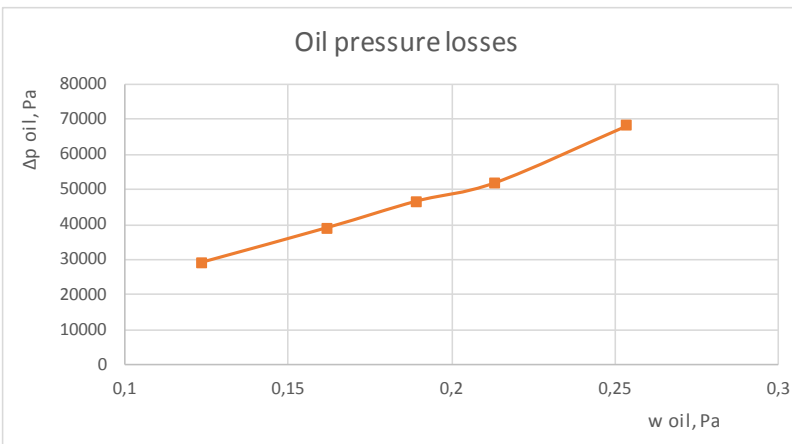

b)

Figure 21. Air and oil pressure losses in dependency on air and oil flow velocity (determined numerically)

Table 9. Oil pressure losses in dependence on oil mass flow rate of a single channel

\begin{tabular}{llllllllll}
\hline \multicolumn{1}{c}{ Parameter } \\
\hline $\begin{array}{c}\text { One channel } \\
\text { mass flow rate }\end{array}$ & 0,001 & 0,003 & 0,007 & 0,01 & 0,015 & 0,02 & 0,025 & 0,03 \\
$\mathrm{G}_{\text {oil 1 ch }}, \mathrm{kg} / \mathrm{s}$ \\
$\begin{array}{c}\text { Oil losses with } \\
\text { ribs } \Delta \mathrm{p}_{\text {rib ch }}, \mathrm{Pa}\end{array}$ & 0,78 & 6,10 & 29 & 57 & 124 & 214 & 323 & 469 \\
$\begin{array}{c}\text { Oil losses } \\
\text { without ribs }\end{array}$ & 0,35 & 2,3 & 10 & 19 & 39 & 64 & 93 & 133 \\
$\begin{array}{c}\Delta \mathrm{p}_{\text {sm ch }}, \mathrm{Pa} \\
\Delta \mathrm{p}_{\text {rib ch }} / \Delta \mathrm{p}_{\text {sm ch }}\end{array}$ & 2,2286 & 2,6522 & 2,9000 & 3,0000 & 3,1795 & 3,3438 & 3,4731 & 3,5263 \\
\hline
\end{tabular}

\section{Discussion}

The following is the thermal and hydraulic parameters analysis of the cooling section obtained by the experimental and numerical methods.

The experimental results analysis was done at fixed mass flow rates of both heat carriers based on exploitation conditions $\mathrm{G}_{\mathrm{oil}}=0.31 \pm 0.1 \mathrm{~kg} / \mathrm{s}$ and $\mathrm{G}_{\text {air }}=0.36 \pm 0.1 \mathrm{~kg} /$ $\mathrm{s}$ respectively. In view of tube parameters changing, velocities (therefore and Reynolds numbers) and heat transfer coefficients are changed, as well, both inside and outside (Figure 7). It is necessary to point at the fact that the flat-finned tube specific gravity changes in the range from 0.802 to $1.025 \mathrm{~kg} / \mathrm{m}$ (Table 4) at the fin height change from 4 to $8.5 \mathrm{~mm}$ (Table 3 ) according to the sample number.

The maximum thermal efficiency fixed for sample 5 having $8 \mathrm{~mm}$ fin height and $2.5 \mathrm{~mm}$ fin pitch in combination with $67.5 \mathrm{~mm}$ tube width and $8.3 \mathrm{~mm}$ tube height with eight inner channels (Table 4, Figure 6). This sample has the largest heat transfer area in comparison with other samples due to thick finning and greater tube width.

It should be noted that sample 1 having similar fin dimensions (and 8.5 fin height) but smaller tube width than sample 5 (therefore, smaller heat transfer area), provides almost the same thermal power transfer. It is explained by the fixed oil flow rate during the experiment. The fact is that sample 1 has smaller oil cross section area than sample 5 has; therefore, the oil velocity in sample 1 is higher than in sample 5. As a result, the heat transfer coefficient of sample 1 is higher and the thermal resistance coefficient of sample 1 is less than the same parameters of sample 5. Thus, sample 1 has the design, which can lower weight and dimensional characteristics of an air-to-oil heat exchanger at fixed parameters of an oil pump unit and fun installation. Meanwhile, samples 2 - 4 having similar small cross-section areas but fin pitches in the range of 2 to $3.75 \mathrm{~mm}$ and fin heights of 4 to $6.5 \mathrm{~mm}$, show the worst results of thermal efficiency.

Sample 7 has the lowest compactness factor and the thermal efficiency value, which is comparable to sample 3. Such a low value of thermal power caused by a big fin pitch and small fin height of the sample 7 design. Therefore, the main reason for low thermal efficiency of sample 7 is poorly developed heat exchange surface.

Sample 6 has the lowest thermal efficiency despite the similar design to sample 5. The most possible reason of this phenomenon is the highest total thermal resistance to heat transfer caused by the nonoptimal sample design. However, in this case, a random error in the acquisition and processing of experimental data is possible, as well.

Thermal power grows steadily with a stable growth of Reynolds number (Figure 7). An increase in Reynolds numbers leads to an increase of turbulence; therefore, the turbulence intensifies the heat exchange process, thereby causing an increase in heat transfer coefficients. Thus, the Reynolds numbers growth has a positive effect on the heat transfer process but a negative effect on the heat exchanger hydraulic characteristics, in particular on pressure losses, so evaluating of power costs for pumping the heat carrier is another significant aspect in heat exchanger design process. 
The mutual influence of both factors (thermal efficiency and pressure losses) on the heat exchanger design can be evaluated with Kirpichev and Antufiev energy efficiency criterions. Usually, high thermal performance is possible to achieve at the simultaneous increase of pressure losses, consequently increasing power costs for pumping the energy carrier.

The highest value of Kirpichev criterion (Figure 8) corresponds to optimal heat exchanger dimensions, which provide the most effective heat transfer at the minimum of power costs for pumping the heat carrier. Samples 1-3 have the highest air side energy efficiency criterion $\left(\mathrm{N}_{\text {air }}\right)$, simultaneously, these samples show worsening Kirpichev criterion concerning the oil side pumping power $\left(\mathrm{N}_{\text {oil }}\right)$ because of the flow area decrease and oil velocity increase in inner channels. Sample 5 has the maximum total Kirpichev criterion $\left(\mathrm{N}_{\text {air }}+\mathrm{N}_{\text {oil }}\right)$ value.

The chart represented in Figure 9 shows that sample 3 has the highest values of Antufiev criterion. Thus, sample 3 has the most profitable indicators of the heat exchanger aerodynamic and hydraulic perfection due to low values of pressure loss, both air and oil sides. However, in comparison with samples 3 and 5, thermal efficiency of sample 3 is much less because of smaller heat transfer area.

Based on the foregoing, it is possible conclude that the most effective thermodynamic performance has sample 5 , but the optimal combination for all the parameters can be considered sample 1.

As it was said before, the main goal of the numerical investigation is obtaining an adequate model of a single cooling section for the subsequent creation of the whole oil cooler model. The cooling section numerical investigation is conducted for different boundary conditions in the oil side and air side parameters range. Figure 22 shows some results of the experimental and numerical data comparison done for samples 1-4 (Table 4) with respect to the main thermodynamic parameters. It can be seen from the graphs in Figure 23 that for the case of six-channel finned tube samples 1-4, good comparability of the natural and numerical experiment results is observed.

The curve trends of the experimental (Figure 6) and numerical (Figure 21b) hydraulic resistance graphs coincide, confirming the adequacy of the numerical model.

The coincidence of experimental and numerical data, confirming the adequacy of the cooling section model, allows to get the first reference point to continue further research with a full-sized oil cooler as part of an automatic air-to-oil heat exchanger in a single container. In this case, a particular interest is the mutual influence of the heat exchange sections to the oil heat exchanger operation. For instance, for the case of a two-row heat exchanger, the following air flow pattern is possible (Figure 24).

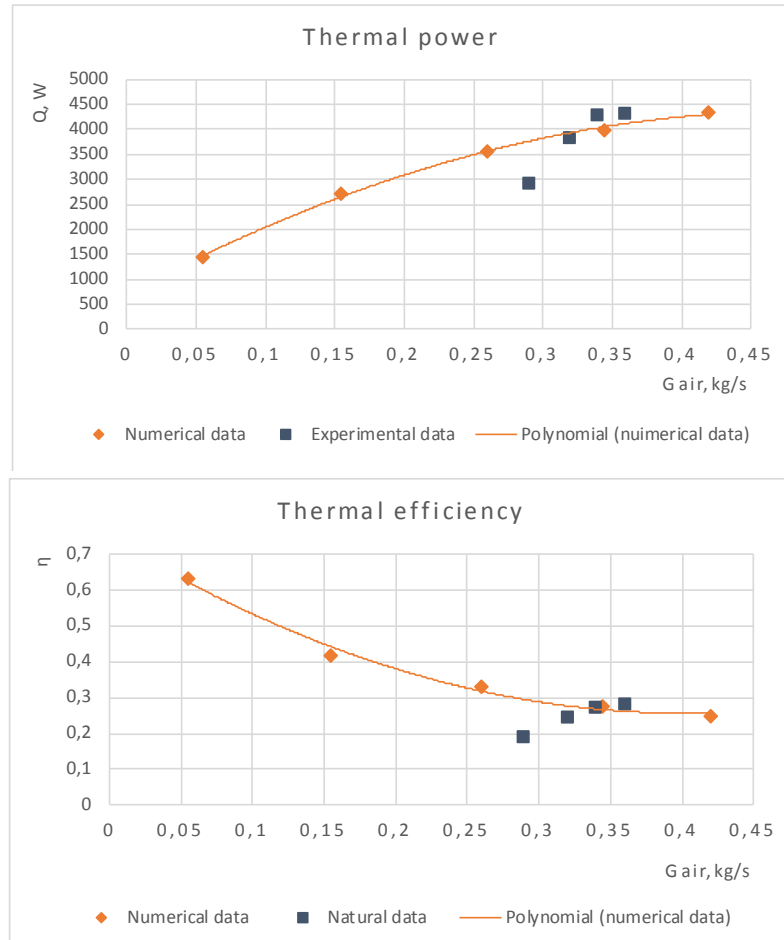

Figure 23. Comparison of numerical and experimental data (thermal parameters)

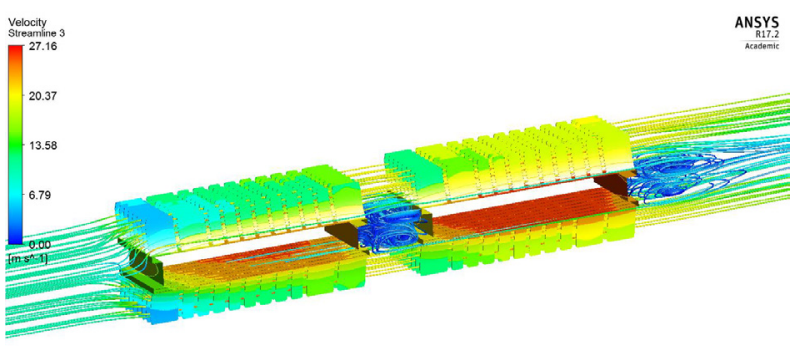

Figure 24. The double-row heat exchanger flow structure of the air domain

\section{Conclusions}

The effective project solution of a modern air-tooil heat exchanger directly depends on an optimal combination of thermal efficiency, geometry and weight characteristics of an exchanger basic element.

The usage of the cooling section with increased thermal efficiency (sample 5) will allow to enhance amount of heat removed by the exchanger insignificantly but the usage the cooling section with optimal dimensional characteristics (sample 3) will allow to get an oil cooler with lower specific quality of metal per structure with almost the 
same efficiency. In addition, the practical application of this section (sample 3) will lead to lower energy costs for pumping, which is important when working as part of an entire lubrication system. Therefore, the design of sample 3 is the most preferable variant for use and installation into the full-sized oil cooler.

As a recommendation, from the aerodynamic point of view, the ends of flat pipes should be produced rounded to reduce air pressure losses. According to studies ${ }^{[1,12]}$ this design allow to increase the thermal hydraulic efficiency in comparison with round and oval pipes having a different layout of ribs.

Despite the good convergence of the natural and numerical investigations results, it should be noted that in this study, heat and mass transfer processes of insulated flat finned tubes were investigated. At the same time, it is necessary to consider that the isolated experimental conditions of the single cooling section test do not correspond to the actual operating conditions as part of a full-sized oil cooler. The mutual influence of the tubes, the effect of collecting and distributing collectors, should be considered as part of a separate study of a fully assembled oil cooler. Additionally, when installing an oil cooler into an automatic air-to-oil heat exchanger, the influence of the walls, internal elements of a container and the influence of external blinds should be taken into account, as well.

For taking into account all of the above factors affecting the heat transfer process, it is important to set the boundary conditions as correctly as possible. However, even in the case of correctly specified boundary conditions, a directed natural experiment is required to confirm the adequacy of the developed model for both the oil cooler and the cooling apparatus in the container.

\section{References}

[1] Chichindaev, A.V., 2009. Teplomassoobmen vlazhnogo vozdukha $\mathrm{v}$ kompaktnikh plastinchato-rebristikh teploobmennikakh, Novosibirsk, NGTU. pp. 298. (in Russian).

[2] Bessonny, A.N., Dreicer, G.A., Kuntish, V.B., 1996. Osnovi rascheta i proektirovaniya teploobmennikov vozdushnogo okhlazhdeniya [Calculation and design foundations of air cooled heat exchangers], St.Petersburg, Nedra Publ. pp. 512. (in Russian).
[3] Pismennii, E.N., 2004. Teploobmen i aerodinamika paketov poperechno-orebrennikh trub, Alterpres Publ. pp. 243. (in Russian).

[4] Popov, I.A., Makhyanov, Kh.M., Gureev, V.M., 2009. Fizicheskie osnovi i promishlennoe primenenie intensifikacii teploobmena: Intensifikaciya teploobmena: monografia, Kazan, Center innovacionnikh tekhnologii. pp. 560. (in Russian).

[5] Deulin, K.N., et al., 2008. Teploobmenny element [The heat exchanging element]. Patent RF, no. RD0039306.

[6] Lemouedda, A., Schmid, A., Franz, E., Breuer, M., Delgado, A., 2011. Numerical investigations for the optimization of serrated finned-tube heat exchangers. Applied Thermal Engineering. 31(8-9), 1393-1401. DOI: https://doi.org/10.1016/j.applthermaleng.2010. 12.035 .

[7] Popov, I.A., Makhyanov, Kh.M., Gureev, V.M., 2009. Phisicheskie osnovi i promishlennoe primenenie intensifikacii teploobmena [Physical foundations and industrial application of heat exchange intensification], Kazan, Center innovacionnikh tekhnologii. pp. 560. (in Russian).

[8] Khabibullin, I.I., Nizamutdinoiv, R.M., Kadyrov, R.G., Nikolaenko, I.V., Gureev, M.V., Tiunov, S.V., 2019. Numerical modelling of heat exchange processes in the oil air cooling device. Gazovaya promishlennost. 2, 84-90. (in Russian).

[9] Bazhan, P.I., Kanevets, G.E., Seliverstov, V.M., 1989. Spravochnik po teploobmennim apparatam, Moskva, Mashinostroenie Publ. pp. 368. (in Russian).

[10] Antufiev, V.I., 1966. Effectivnoct razlichnikh form konvektivnikh poverkhnostei nagreva. Mockva, Energiya Publ. pp. 183. (in Russian).

[11] Pismennii, E.N., Demchenko, V.G., Terekh, A.M., 2010. Ecomomaizer-utilizator iz plosko-ovalnikh trub s nepolnim orebreniem. Vostochno-evropeiskii zhurnal peredovikh tekhnologii. no 3/1(45). pp. 1519 (in Russian).

[12] Judin, V.F., Fedorovich, E.D., 1991. Teploobmen puchkov orebrennikh trub ovalnogo profilya. Teplomassoobmen. MMF-92. Konvektivnii teplomassoobmen. Vol. 1, part 1, Minsk, ANK ITMO ANB. pp. 58-61 (in Russian). 